\title{
Farmers' Perception and Constraints to the Adoption of Weed Control Options: the Case of Striga asiatica in Malawi
}

\author{
Evans Atuti Atera (Corresponding author) \\ Technical Services Department, Lake Basin Development Authority \\ P.O. Box 1516-40100, Kisumu, Kenya
}

Tel: 254-57-202-7227_E-mail: eatera@yahoo.com

Kazuyuki Itoh, Tetsushi Azuma \& Takashige Ishii

Graduate School of Agricultural Science, Kobe University

1-1, Rokkodai, Nada, Kobe, 657-850, Japan

Received: November 21, 2011

Accepted: December 15, $2011 \quad$ Online Published: April 1, 2012

doi:10.5539/jas.v4n5p41

URL: http://dx.doi.org/10.5539/jas.v4n5p41

\begin{abstract}
Studies were conducted to determine farmers' perception on Striga control options and their potential for adoption in two Extension Planning Areas (EPAs) in Central Malawi. Individual interviews were conducted in Mpingu (Lilongwe District) and Mponela (Dowa District) EPAs in 2010 in a sample of 247 respondents. The study revealed that crop production was the main source of livelihood for most households. Farmers identified Striga as a constraint to maize production and attributed its increasing incidence to insufficient funds to purchase inputs, soil fertility and grazing animals. On Striga control mechanisms, manure application was perceived to be the best by farmers, followed by crop rotation, fertilizer application and hand pulling. Even though Striga infestation is increasing in farmers fields, they have not adopted the control options. The low adoption of the options has been justified as "too risky" as farmers do not trust them. Emphasis should be laid on undertaking on-farm trials and development of technologies should involve farmers if they are to gain wide acceptability.
\end{abstract}

Keywords: Striga asiatica, Farmers, Perception, Control mechanisms, Malawi

\section{Introduction}

The parasitic angiosperm, Striga spp., is obligate root parasite endemic in sub-Saharan Africa causing severe constraint to cereals. It is a growing pandemic, undermining the struggle to attain food security of the continent. Approximately $40 \%$ of the cereal producing area is infected and 300 million people affected (Ejeta, 2007). The most affected are subsistence farmers losing about 20-80\% of their crop yield (Atera et al., 2011). In Malawi, the recorded species are $S$. asiatica, S. aspera, S. gesneriodes and S. forbesii. Among these, S. asiatica is said to be widespread and the most noxious to cereal crops such as maize, sorghum, millet and rice (Kabambe et al., 2008).

The parasite is estimated to be infecting 268,000 ha of farm land in Malawi (AAFT, 2006). A survey carried out in the country showed that $63 \%$ of the maize is infested (Kroschel et al., 1999). The figure has since risen to $80 \%$, an indication that Striga problem is not declining (Parker, 2009). Total crop yield loss occurs under heavy infestation. Other losses as result of Striga depend on land use system, soil fertility, crop species and genotype, and rainfall patterns (Atera et al., 2011). The parasite is difficult to control because it has the capacity to produce large number of tiny dust like seeds which can survive in the soil for more than 10 years (Hearne, 2009). These seeds do not germinate unless they are stimulated by root exudates of their hosts.

The life cycle of the parasite is closely interlinked to that of its host and largely depends on chemical signals. This is a challenge to researchers particularly in understanding host-parasite biology. Several germination stimulants have been recorded that trigger Striga germination; however, strigolactones are the most common root exudates from many cereals (Scholes \& Press, 2008). Knowledge of the biosysthetic pathways is required so that production of germination stimulants can be manipulated to identify genes involved in the synthesis and 
regulation of strigolactones. This might probably lead into designing a novel control strategy. Contrary to normal weeds, most of the damage to the host is done before the parasite emerges above the soil (Kiwia et al., 2009; Atera et al., 2012). Therefore, control methods should focus on reducing soil seed bank and interfere with the parasite's early developmental stages.

Various Striga control options such as use of resistant crop varieties, cereal-legume intercropping, trap crops that stimulate suicidal germination and nitrogen fertilizer application have been suggested (Frankie et al., 2006; Hooper et al., 2009). A combination of a wide range of technologies into an integrated Striga control (ISC) program has been identified as a feasible approach to contain the parasite. The adoption and successful implementation of this technology largely depend on farmers' perception and reaction towards it. The objective of this research was to determine farmers' knowledge and, perceptions of Striga and its control options in Malawi to serve as basis for development, assessment and adaptation of the options by farmers.

\section{Methodology}

The study was conducted in January to March 2010 in two districts (Dowa and Lilongwe) in the central region of Malawi, where Striga has been a problem. With the help of Ministry of Agriculture (MoA) extension staff, one Extension Planning Area (EPA) (Mponela, Dowa District and Mpingu, Lilongwe District) was selected in each district (Figure 1). Six villages within the locations of these EPAs were selected. Farmers' from each village were selected randomly from the list in the office of agricultural extension staff. Within the six villages from each EPA, a sample of 118 and 129 households in Mpingu and Mponela EPA were selected for data collection and response was $96 \%$. Forty three (43) open structured household level questionnaires were administered.

The survey captured the farmer's characteristics such as sex, age, educational level, farming experience and access to information on farming. It also covered farming technologies, constraints to agriculture and Striga and its control strategies. This information was meant to collate the perceptions of farmers to production constraints. Data were collected through a field survey by face-to-face interviews with the farmers by trained enumerators and agricultural extension staff. Farmers were invited to be part of the survey through agricultural extension agents and opinion leaders.

Crops of preference were ranked and simple scores used to reflect the farmers' perception on constraints to agricultural technologies and Striga management approach. The simple scores were developed to show how well certain farming and Striga control strategies met farmers' preferences. In each technology, ordinary numbers were used as bench marks to rank and score its importance. Farmers' perception was judged on a scale and determined by following equation:

$$
w=\frac{\sum_{n=1}^{N} \sum_{i=1}^{x} \text { ain }}{x}
$$

$\mathrm{W}=$ weight of factor

$i=1 \ldots \ldots \ldots \ldots \ldots \ldots \ldots . . . . \ldots$

$\mathrm{n}=1 \ldots \ldots \ldots \ldots \ldots \ldots \ldots \ldots \ldots$

$\mathrm{x}=$ Number of factors

$\mathrm{N}=$ Number of sample

$\mathrm{a}=$ Value of factor $i$ for the sample number $n$.

Through the interviews, farmers provided primary information on their opinion and challenges on both agriculture and Striga. Reviews were conducted before interviews to ascertain the available farming technologies, farmers' constraints and if the proposed technologies fit within their farming systems. We adapted sections of Manyong et al. (2008) survey in identifying the rationale for non-adoption of Striga control mechanisms. Data from the questionnaire were analyzed using the statistical package for social scientists (SPSS) software. The results presented in this paper are perceptions of farmers about Striga asiatica and its control options.

\section{Results and Discussion}

\subsection{Household Characteristics}

In the study, most of the sampled households (76.3\%) were headed by males. This represented typical household headship in African societies, where women can assume headship after becoming widows. The study revealed 
that $85.6 \%$ and $76 \%$ of the household heads received formal education in Mpingu EPA and Mponela EPA, respectively. Mpingu EPA also had more (4.3\%) respondents trained in vocational and short-term training on farming skills. This may be as result of proximity to Lilongwe City and Chitedze Research Station which offers opportunities for urban based training on agriculture. There were several Non Governmental Organizations (NGOs) involved in offering training to rural poor farmers in Lilongwe District compared to Dowa District. The study showed that educational level is one of the most important attributes that indicates a household capacity to adopt technology. In both EPAs, the average household heads were in their economically active age of about 45 years. There were more household heads working off the farm in Mpingu EPA (17.3\%) than Mponela EPA (8\%). Of the sampled population, most households owned about 0.9 ha of land.

\subsection{Importance of Crop Production to the Local Communities' Livelihood}

The study revealed that agriculture is the livelihood source for the communities in the two EPAs, Mpingu and Mponela. Maize (Zea mays [L.]) is regarded as source of food (Table 1) and it is produced by almost every farmer. It is also considered by some farmers as source of income. Maize is life "chimanga ndi moyo" to many farmers in Malawi for its famous use to prepare the stable dish nsima. Our result is related to Kabambe et al. (2008) who reported that maize constituted a major component in the diet of Malawian people. Theu (2008) revealed that $55-60 \%$ of the maize grown in Malawi comes from the central districts, and the area is most affected by Striga asiatica. This indicates the importance of maize in the study area and the need to address constraints that reduce its productivity.

Maize-legume intercropping was generally practiced among farming households to reduce Striga. This agrees with the findings of Mbwaga et al. (2001) that intercropping cereals with legumes reduced Striga infections and increased yield in Cameroon and Ethiopia. The cropping system not only increases yield but soil fertility is improved by nitrogen fixation and soil erosion reduced. Odhiambo and Ariga (2001) reported that maize-bean intercropped in the same hole increased maize yield by $78.6 \%$ above the pure stand in heavy Striga infected area. Intercropping maize with desmodium has also been shown to reduce Striga incidence in Kenya through allelopathic effect (Khan et al., 2007) and the same to sesame intercropped with sorghum and pearl millet in Eritrea (ICRISAT, 2002). These findings clearly testify that inclusion of legumes in cereal-based systems has beneficial effects in reducing Striga incidence resulting to enhanced cereal yield.

Traditional non tradable crops such soybeans (Glycine max), groundnuts (Arachis hypogeal), sweet potatoes (Ipomea batatas) and cassava (Manihot esculenta) were widely grown in the study sites. The study revealed that groundnuts and sweet potatoes were the second most important crops and production was fairly well spread between the study sites (Table 1). With most households engaged in crop production, the largest number of crop species produced by farmers was from Mpingu compared to Mponela. According to Moyo (2010) legumes are important components of Malawi's maize based farming system. Despite the benefits which can be accrued from legumes, the sub-sector is characterized by low productivity due to the fact that farmers experience serious problems of accessing seeds at planting time. The focus of the agricultural sector is to use innovative systems of approach to increase farmers' access to seed and use research to address production and marketing bottlenecks in the legume value chain.

\subsection{Farmers Perception on Striga as a Cause to Food Insufficiency}

In this study, farmers were asked to rank the crops in order of priority as a source of food and cash. The four most important crops in the study area were maize, sweet potatoes, groundnuts and cassava (Table 1). However, there were some differences within the sampled population in each EPA as well as within males and females. For instance, farmers in Mponela considered Bambara beans as the eighth important crop while only males rated irish potato as the sixth in descending order of importance. In both EPAs, the most important crop (maize) was infected with Striga asiatica. A leguminous parasitic plant Alectra vogelii which most farmers referred as "Kaufiti" a local name for Striga infected groundnuts, bambara beans, common beans and soybeans, which are farmers preferred legumes crops.

Striga infestation in the farmer fields ranged from mild to severe infestation. The survey revealed that $67 \%$ of farmers in the study area have Striga in their fields. Almost all farmers (91.3\%) viewed Striga as a challenge to crop production. Lack of funds to purchase inputs (20.4\%) and farm tools $(13.7 \%)$ in the study sites were recorded as the major causes of insufficient food (Table 2). About $10.5 \%$ of the respondents stated that weed infestation was responsible for low productivity in the agricultural sector. AAFT (2009) identified lack of inputs and Striga infestation as the major constraint to crop productivity which is consistent with our findings. In order to improve on food sufficiency, the Government of Malawi introduced farm input subsidy program (FISP) known as "starter pack" (SP) which provided farmers with packs of fertilizer, maize and beans or ground nuts to 
rural households. The inclusion of legumes in FISP was taken to improve on the soils and yield as well as to reduce Striga infections (MoAIFS, 2005). As much as the government subsidized the price of fertilizer, the targeted farmers still cannot afford it in sufficient quantities because they are capital constrained when the planting season sets in.

\subsection{Perception of Farmers on Striga Increase in Their Fields}

The majority of farmers from the two EPAs attributed lack of capital to purchase inputs as the major problem that has aggravated increase of Striga. In addition, farmers Mponela EPA considered low soil fertility and poor land preparation due to mono-cropping increased Striga incidence in their fields. However, Mpingu farmers claimed that sharing of seeds for planting from previous harvest for planting aggravated Striga incidence. Respondents from both EPAs acknowledged that movement of animals especially cattle after harvesting aggravated the Striga problem by disseminating the seeds on their hooves and dung. They viewed the grazing animals and wind as the major agents of Striga dissemination to new areas. These findings are similar to those of Emechebe et al. (2004) that Striga seeds are often disseminated by cattle and contaminated seeds in northern Nigeria. Farmers were willing to try new technologies which do not require additional capital. They felt that there was need to reduce the Striga seed banks and prevent further seed dissemination to new areas.

\subsection{Farmers Knowledge on Farming Methods and Striga Control Technologies}

The study showed that farmers major source of information on modern farming methods and Striga control technologies are from government extension staff (Figure 2). Approximately $26 \%$ of the respondents viewed International Organizations/NGOs as playing a significant role in providing farmers with knowledge on farming techniques. Most farmers gained access to knowledge on Striga from the extension services $(33 \%)$ and neighbors (23\%). The view is probably related to Oswald (2005) who showed that even extension staff in Kenya did not have enough knowledge on Striga and only 34\% of farmers received training on Striga from them, while the rest depended on their neighbors.

Interestingly, the media service (TV and radio) was ranked third as the source of information for farmers on Striga. Radio as media of information in particular, is very popular as it reaches a wide audience and is very accessible and affordable. The government has ensured that there are live programs and forums making it possible for presenters to interact with farmers. Nevertheless, the study revealed that research institutions are not instrumental in technology dissemination even though they are prominent in the generation.

\subsection{Farmers Perception on Effectiveness of Striga Control Mechanisms}

Majority of the respondents (74.2\%) admitted that they usually applied the technologies used to manage normal weeds (Conyza stricta, Solanum incanum, Oxalis latifolia etc.) to control Striga. The management practices of these weeds are ineffective in controlling parasitic weeds. Farmers in both EPAs ranked manure application as the most popular and best option in Striga control (Figure 3). This implies that consistent manure application is perceived to reduce Striga populations. However, Smaling et al. (1991) reported that effects of N, P, S and farmyard manure were disappointing as none of them suppressed Striga significantly. In addition, Manyong et al. (2008) stated that manure increases nutrients in the soil for crops to grow well, but it does not reduce Striga seed bank.

Crop rotation and fertilizer application were ranked highly while intercropping was among the best mechanism with the farmers. According to the farmers, crop rotation and intercropping provided additional benefits. They reported that other than having extra food crop in the field, the methods appear to be creating crop sequences with varying patterns of resource competition, allelopathic interference and soil disturbance, thus providing unstable environment that prevents proliferation of particular weed species. In addition, the resources that become available through failure of one crop species can be used by the surviving crop. This view is probably related to Ransom (2000) and Oswald and Ransom (2001), who showed crop rotation as a farming system that can reduce Striga infestation and fits the small scale subsistence farmers with their limited resources. However, the average Malawian farmer has a land holding of about 0.9 ha. Practicing crop rotation as a farming system is not viable considering the small land ratio. Several farmers may be forced into nomadic life of searching for hired labor to feed their families because the land may not produce their food requirement.

The use of herbicide coated seeds such as imazapyr-resistant maize (IR maize) which has been perceived by researchers (De Groote et al., 2008) as the best option to contain the Striga menace was ranked poorly (Figure 3). The farmers felt that purchasing of seeds every planting season is not affordable due to poverty. That notwithstanding, Oswald (2005) reported that the IR maize has serious drawback as resistance of herbicide is 
based on a single recessive gene. Therefore, any crossing of this maize will result to plants that are no longer resistance.

\subsection{Non-adoption of Striga Control Mechanisms}

Farmers in the study sites had varied reasons on non-adoption of control mechanisms. They expressed fears of investing in the Striga prone areas as the losses incurred were huge. The result revealed that $30.8 \%$ of the respondents perceived the technologies as too risky to adopt and have no guarantee of direct payoff in crop yield increase, while $20.8 \%$ of the respondents pointed out that they lacked cash to purchase inputs (Figure 4). More than $15.1 \%$ of respondents in Mpingu EPA indicated that improved crop varieties were better in Striga control while 20.6\% in Mponela EPA were still gathering more information on the technologies. The respondents openly disclosed that they feared some of the technologies as they did not have enough information on them.

From these results, it was evident that most farmers (48\%) do not know how to handle witchweeds despite the availability of the recommended options. Some of the options are beyond the farmers reach in terms of their resources. This result corroborate the views of Oswald (2005) in a survey of 198 randomly selected farming households in western Kenya, where $11 \%$ of the farmers knew that Striga propagate by seed while $51 \%$ did not know how it propagates. A similar study conducted in Ghana showed that $36 \%$ of farmers knew Striga produce seed and 56\% thought it produced stolons (Ransom, 2000). These results are indications that farmers need knowledge and training. Furthermore, Hearne (2009) reported that non adoption of Striga control options may be as result of reliability of technologies, poor access and cost of technologies, limited practicality of the methods, and poor information.

\section{Conclusion}

Significant investment in research has been directed towards the study of Striga in the last 30 years, resulting to increased understanding of the witchweed life cycle and biology as well as development of control options. Lack of sufficient knowledge on Striga has been a setback to farmers in adoption of control mechanisms in most developing countries. It is necessary to establish whether research findings on Striga control options are imbedded in books and journals which make it difficult for farmers to access them. Participatory approach in Striga research involving farmers, scientists and extension personnel at all stages will promote knowledge sharing and acquisition. This approach may accelerate the process in which farmers participate in testing the options and subsequently adaptation.

\section{Acknowledgements}

This paper is the product of a project funded by the Mitsui Corporation (08-C-083). The authors acknowledge the contributions of extension staff, Ministry of Agriculture, Malawi, enumerators and farmers who participated in this survey.

\section{References}

AATF. (2009). Baseline study of smallholder farmer in Striga-infested maize growing areas of Central Malawi. African Agricultural Technology Foundation Nairobi, Kenya, pp 1-94.

AATF. (2006). Empowering African farmers to eradicate Striga from maize croplands. African Agricultural Technology Foundation. Nairobi, Kenya, pp 17.

Atera, E. A., Itoh, K., Azuma, T. \& Ishii, T. (2012). Response of NERICA rice to Striga hermonthica infections in western Kenya. International Journal of Agriculture and Biology, 14, 271-275.

Atera, E. A., Itoh, K. \& Onyango, J. C. (2011). Evaluation of ecologies and severity of Striga weed on rice in sub-Saharan Africa. Agriculture and Biology Journal of North America, 5, 752-760. http://dx.doi.org/10.5251/abjna.2011.2.5.752.760

De Groote, H., Wangare, L., Kanampiu, F., Odendo, M., Diallo, A. \& Karaya, H. (2008). The potential of a herbicide resistant maize technology for Striga control in Africa. Agriculture Systems, 97, 83-94. http://dx.doi.org/10.1016/j.agsy.2007.12.003.

Ejeta, G. (2007). The Striga scourge in Africa: a growing pandemic. In: Ejeta G. and Gressel J. (eds), Integrating New Technologies for Striga Control. World Scientific Conference, Singapore, pp 3-16.

Emechebe, A. M., Ellis-Jones J., Schulz, S., Chikoye, D., Douthwaite, B., Kureh, I., Tarawali, G., Hussaini, M. A. \& Kormawa, P. (2004). Farmers' perception of the Striga problem and its control in Northern Nigeria. Experimental Agriculture, 40, 215-232. http://dx.doi.org/10.1017/S001447970300160 
Franke, A. C., Ellis-Jones, J., Tarawali, G., Schulz, S., Hussaini, M. A., Kureh, I., White, R., Chikoye, D., Douthwaite, B., Oyewole B. D. \& Olanrewaju, A. S. (2006). Evaluating and scaling-up integrated Striga hermonthica control technologies among farmers in northern Nigeria. Crop Protection, 25, 868-87. http://dx.doi.org/10.1016/j.cropro.2005.11.014

Hearne, S. J. (2009). Control - the Striga conundrum. Pest Management Science, 65, 603-614. http://dx.doi.org/10.1002/ps.1735

Hooper, A. M., Hassanali, A., Chamberlain, K., Khan Z. \& Pickett, J. A. (2009). New genetic opportunities from legume intercrops for controlling Striga spp. parasitic weeds. Pest Management Science, 65, 546-552. http://dx.doi.org/10.1002/ps.1731

ICRISAT. (2002). Sorghum, Striga, and shattercane: A report of a biodiversity mission to Eritrea. International Crops Research Institute for the Semi Arid Tropics, Nairobi, Kenya.

Kabambe, V., Katunga, L., Kapewa T. \& Ngwira, A. R. (2008). Screening legumes for integrated management of witchweeds (Alectra vogelii and Striga asiatica) in Malawi. African Journal of Agricultural Research, 3, 708-715.

Khan, Z. R., Midega, C. A. O., Hassanali, A., Pickett J. A. \& Wadhams, L. J. (2007). Assessment of different legumes for the control of Striga hermonthica in maize and sorghum. Crop Science, 47, 730-736. http://dx.doi.org/10.2135/cropsci2006.07.0487.

Kiwia, A., Imo, M., Jama, B. \& Okalebo, J. R. (2009). Coppicing improved fallows are profitable for maize production in Striga infested soils of western Kenya. Agroforestry Systems, 76, 455-465. http://dx.doi.org/10.1007/s10457-009-9221-2

Kroschel, J. (1999). Analysis of the Striga problem, the first step towards future joint action, in Advances in Parasitic Weed Control at On-Farm Level. In: Joint Action to Control Striga in Africa, Kroschel, J., H. Mercer-Quarshie and J. Sauerborn (Eds). Margraf Verlag, Wekersheim, Germany, pp 3-25.

Manyong, V. M., Nindi, S. J., Alene, A. D., Odhiambo, G. D., Omanya, G., Mignouna H. D. \& Bokanga, M. (2008). Farmers perception of Imazapyr-Resistant (IR) maize technology on the control of Striga in Western Kenya. Nairobi, Kenya: African Agricultural Technology Foundation, pp 3-50.

Mbwaga, A. M., Massawe, C. R., Kaswende A. M. \& Hella, P. (2001). On-farm verification of maize-cowpea intercropping on the control of Striga under subsistence farming. Seventh Eastern Africa regional maize conference, pp 150-167.

MoAIFS. (2005). Ministry of Agriculture, Irrigation and Food Security. A guide to agriculture and natural resources management in Malawi: Agriculture extension branch. Lilongwe, Malawi.

Moyo, N. (2010). Legume platform: Establishing a functional legume seed supply system in Malawi. RIU Malawi, Africa country annual report, 2009-2010, pp 1-3.

Odhiambo, G. D. \& Ariga, E. S. (2001). Effect of intercropping maize and beans on Striga incidence and grain yield. Seventh Eastern and Southern Africa, Regional Maize Conference, pp 183-186.

Oswald, A. (2005). Striga control-technologies and their dissemination. Crop Protection, 24, 333-342. http://dx.doi.org/10.1016/j.cropro.2004.09.003

Oswald, A. \& Ransom, J. M. (2001). Striga control and improved farm productivity using crop rotation. Crop Protection, 20, 113-120. http://dx.doi.org/10.1016/S0261-2194(00)00063-6

Parker, C. (2009). Observations on the current status of Orobanche and Striga problems worldwide. Pest Management. Science, 65, 453-459. http://dx.doi.org/10.1002/ps.1713

Ransom, J. K. (2000). Long-term approaches for the control of Striga in cereals: field management option. Crop Protection, 19, 759-763. http://dx.doi.org/10.1016/S0261-2194(00)00101-0

Scholes, J. D. \& Press, M. C. (2008). Striga infestation of cereal crops - an unsolved problem in resource limited agriculture. Current Opinion in Plant Biology, 11, 180-186. http://dx.doi.org/10.1016/j.pbi.2008.02.004

Smaling, E. M. A., Stein A. \& Sloot, P. H. M. (1991). A statistical analysis of the influence of Striga hermonthica on Maize yields in fertilizer trials in Southwestern Kenya. Plant and soil, 138, 1-8. http://dx.doi.org/10.1007/BF00011801

Theu, M. P. K. J. (2008). Biological control of the witchweed (Striga) in maize (zea mays) in Malawi. Chitedze Research Station. www.cab.org/gara, pp 1-14. 
Table 1. Farmers crop priority ranking in Mpingu (Lilongwe District) and Mponela (Dowa District) EPA in Central Malawi (1= highest)

\begin{tabular}{|c|c|c|c|c|}
\hline \multirow{2}{*}{ Crop } & \multicolumn{2}{|c|}{ Mpingu $^{\S}$} & \multicolumn{2}{|c|}{ Mponela } \\
\hline & Male & Female & Male & Female \\
\hline Beans & - & 6 & 7 & 5 \\
\hline Cassava & 5 & 4 & 5 & 6 \\
\hline Groundnuts & 3 & 2 & 3 & 2 \\
\hline Irish potato & - & - & 6 & - \\
\hline Maize & 1 & 1 & 1 & 1 \\
\hline Soybean & 6 & 5 & 4 & 4 \\
\hline Sweet potato & 2 & 3 & 2 & 3 \\
\hline Vegetables & 4 & - & - & - \\
\hline
\end{tabular}

${ }^{\S} 11$ crops listed, ${ }^{\dagger} 14$ crops listed with bambara beans ranked $8^{\text {th }}$ by male, - crops not ranked.

Table 2. Constraints to agricultural production in Mpingu and Mponela EPA in Malawi

\begin{tabular}{|c|c|c|c|c|c|}
\hline \multirow{2}{*}{$\begin{array}{l}\text { Agricultural production } \\
\text { constraints }\end{array}$} & \multicolumn{2}{|c|}{ Mpingu } & \multicolumn{2}{|c|}{ Mponela } & \multirow{2}{*}{ Mean } \\
\hline & Male & $\overline{\text { Female }}$ & Male & Female & \\
\hline Disease and pest & 0.48 & 0.50 & 0.46 & 0.68 & 0.53 \\
\hline Drought & 0.53 & 0.60 & 0.44 & 0.54 & 0.53 \\
\hline Floods & 0.08 & 0.10 & 0.12 & 0.14 & 0.11 \\
\hline Insufficient funds & 0.84 & 0.83 & 0.81 & 0.71 & 0.80 \\
\hline Lack of agricultural technology & 0.33 & 0.27 & 0.43 & 0.48 & 0.38 \\
\hline Lack of equipment & 0.50 & 0.63 & 0.56 & 0.46 & 0.57 \\
\hline Lack of market & 0.46 & 0.26 & 0.38 & 0.46 & 0.39 \\
\hline Shortage of land & 0.37 & 0.33 & 0.68 & 0.57 & 0.49 \\
\hline Weed infestation & 0.41 & 0.47 & 0.28 & 0.60 & 0.44 \\
\hline
\end{tabular}

Values within each column are weight transformed calculated according to the equation in the methodology reflecting farmers' perceptions. 


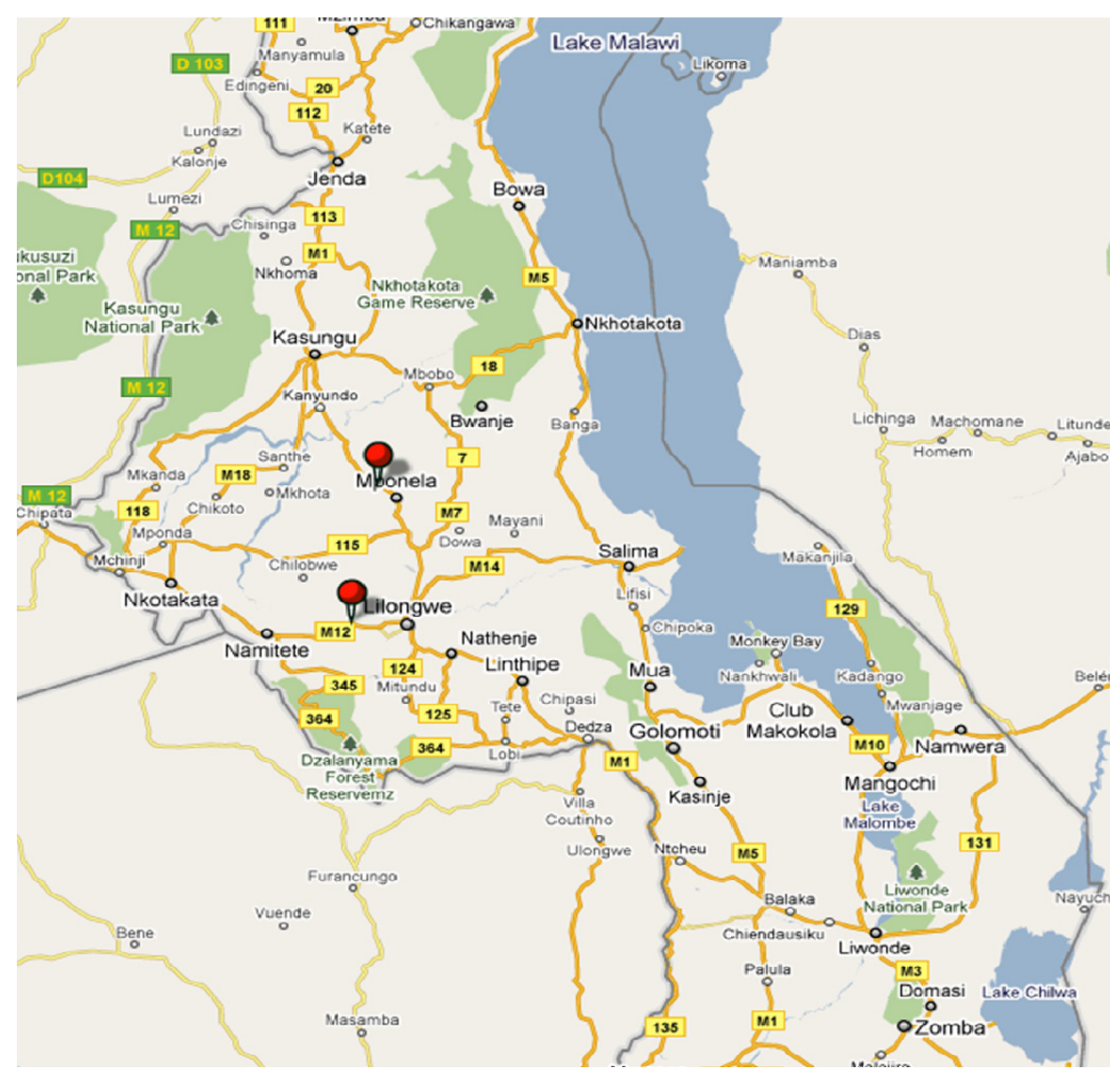

Figure 1. Map of Central Malawi, showing the locations of Mponela (Dowa District) and Mpingu (Lilongwe District) EPA where households were sampled in 2010 


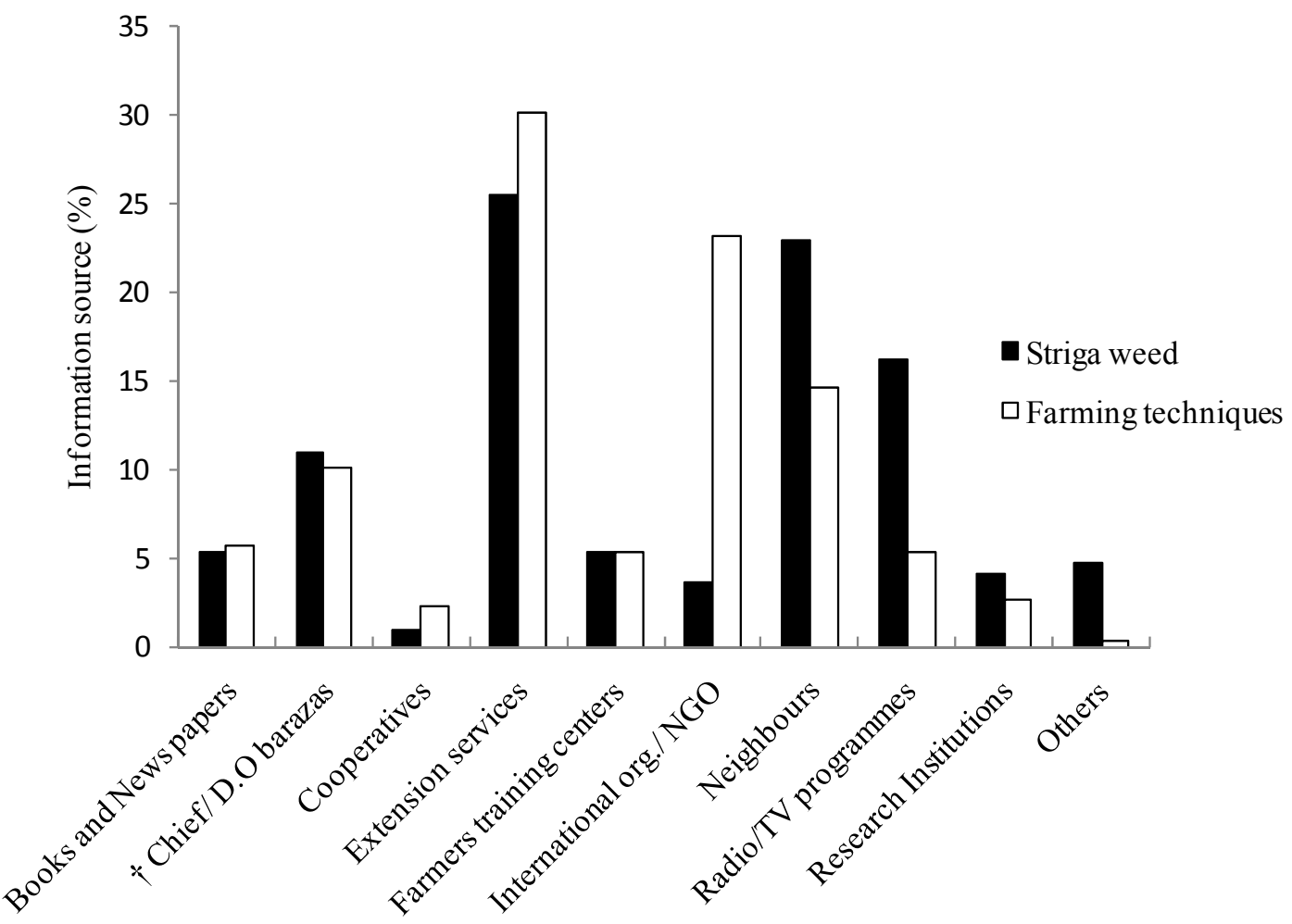

Figure 2. Farmers sources of information on farming techniques and Striga weed. ${ }^{\dagger}$ Chief/District Officer Barazas-means gathering held to raise awareness and share collective information

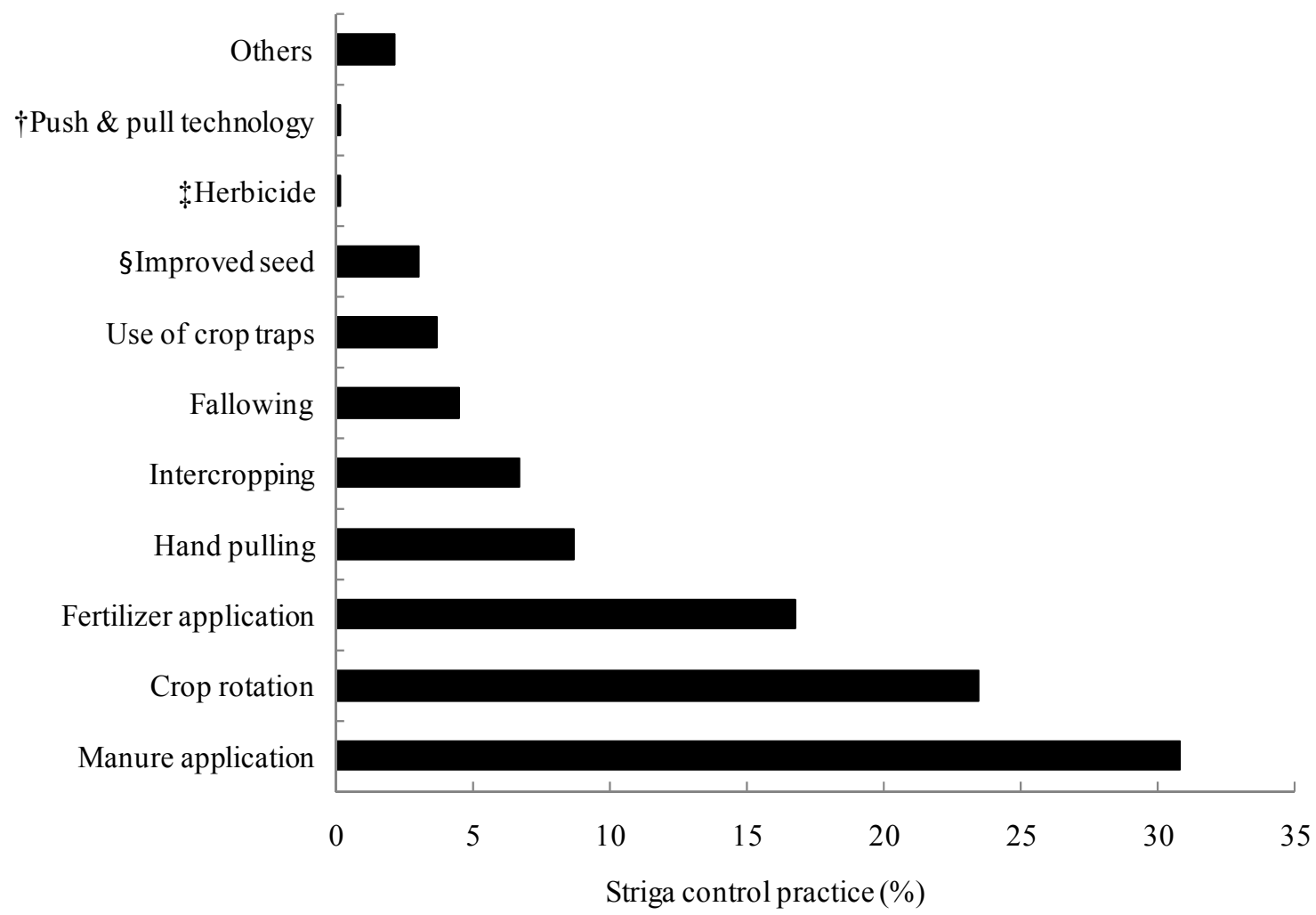

Figure 3. Farmers perception on the control mechanisms popularity $(n=58)$. Integrated management of stem borers, Striga weed and soil fertility, ${ }^{\S}$ Striga tolerant varieties, "Imazapy resistant herbicide-coated maize seed

(IR maize) that forms protective zone around the roots of maize under the name of StrigAway ${ }^{\mathrm{TM}}$ 


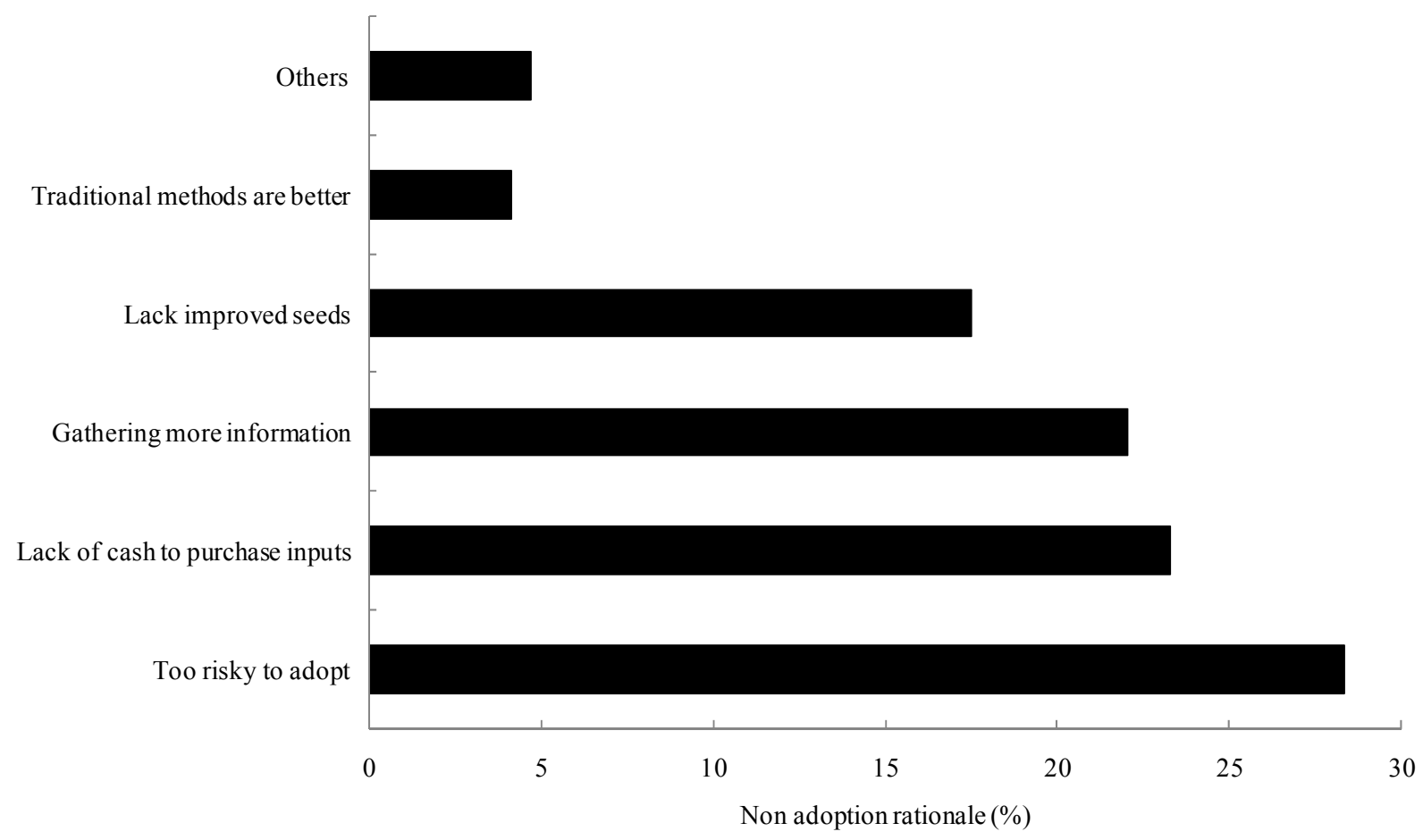

Figure 4. Farmers' reasons for non adoption of the control mechanisms in Mpingu and Mponela EPA 